Full length article

\title{
Early health, risk aversion and stock market participation
}

\author{
Petri Böckerman ${ }^{\mathrm{a}, *}$, Andrew Conlin ${ }^{\mathrm{b}}$, Rauli Svento ${ }^{\mathrm{b}}$ \\ a Jyväskylä University School of Business and Economics (JSBE), Labour Institute for Economic Research and IZA, Finland \\ ${ }^{\mathrm{b}}$ Department of Accounting, Economics and Finance, Oulu Business School, Pentti Kaiteran katu 1, 90570, Oulu, Finland
}

\section{A R T I C L E I N F O}

Article history:

Received 1 April 2021

Accepted 26 August 2021

Available online 31 August 2021

JEL classification:

I100

G110

Keywords:

Health status

Birth weight

Risk aversion

Stock market participation

\begin{abstract}
A B S T R A C T
To examine the relationship between early health status and financial decisions in adulthood, we link information on birth weight in 1966 from the Northern Finland Birth Cohort to data from the Finnish Central Securities Depository over the period of 1995-2010. We find that persons predisposed to poor health status in early childhood (indicated by low birth weight) avoid participating in the stock market in adulthood, with a $10 \%$ increase in birth weight associated with a $1.9 \%$ increase in probability of participation. The link between birth weight and stock market participation is partially channeled by poor early health status being associated with higher risk aversion. Early health status is not significantly related to risk taking in terms of the stock portfolio's composition.
\end{abstract}

(C) 2021 The Author(s). Published by Elsevier B.V. This is an open access article under the CC BY license (http://creativecommons.org/licenses/by/4.0/).

\section{Introduction}

Several studies have investigated the effects of early life conditions on economic outcomes later in life, the well-known "fetal origins hypothesis" (see, for example, Almond and Currie, 2011). Early conditions in life are vital for the determination of outcomes in adulthood. For example, the health endowment developed by the age of 10 is a significant contributor to health differences observed at age 30 (Heckman et al., 2006). Birth weight is concise and one of the most tracked summary metrics of early health status that has been used in the medical and epidemiological literature (Barker, 1990; Corman et al., 2017). Along with health and health-related outcomes, the literature has related birth weight to key economic outcomes such as educational attainment and earnings in adulthood (Behrman and Rosenzweig, 2004; Black et al., 2007).

Classical asset pricing theory suggests that in frictionless financial markets households should allocate a positive fraction of financial wealth to risky stock because expected returns on equity are substantially higher than the risk-free rate, regardless of the risk attitude or the wealth levels of the investors. Therefore, one should expect a $100 \%$ stock market participation by households. However, empirically, we observe that a very high percentage of households do not own any stock (Arrow, 1965). The literature

\footnotetext{
* Correspondence to: Jyväskylä University School of Business and Economics (JSBE), Labour Institute for Economic Research and IZA, Pitkänsillanranta 3A, FI-00530 Helsinki, Finland.

E-mail addresses: petri.bockerman@labour.fi (P. Böckerman), andrew.conlin@oulu.fi (A. Conlin), rauli.svento@oulu.fi (R. Svento).
}

has proposed various economic explanations for this puzzle, including transactions costs (as proxied by education level), and background risks (risks that cannot be hedged, such as those associated with housing, entrepreneurship, or human capital). More recent evidence shows that financial decisions are affected by a wide range of cognitive and non-cognitive factors, such as IQ and personality traits (Grinblatt et al., 2011; Conlin et al., 2015). An obvious but relatively unexplored candidate for explaining financial decisions in adulthood is early health endowment.

This paper links early health status to financial decisions in adulthood. We contribute to the literature on the determinants of risk aversion and household differences in stock market participation. To accomplish this, we use longitudinal data containing information on measured birth weight combined with a comprehensive official register that keeps information on the holdings of Finnish investors in securities that are registered in Finland. Notably, our data also contain information on risk aversion in adulthood.

There are good reasons to expect that financial decisions in adulthood are partially affected by health endowment in childhood (Edwards, 2008). Poor health may, for instance, induce changes in time preferences (i.e., tradeoffs between present and future consumption). Consequently, individuals with poor health most likely discount the future more heavily. Chronic health problems may shorten planning horizon and lead to the avoidance of risky financial choices. ${ }^{1}$ A central mechanism for this is

\footnotetext{
1 Our data do not contain information on planning horizons or expected longevity.
} 
that poor health potentially contributes to risk aversion (Decker and Schmitz, 2016), which is a fundamental determinant of investment in risky assets (Merton, 1969). As a result, stock market participation may be substantially lower for those who have had poor health from childhood.

The relatively sparse empirical literature on health status and financial decisions has used mainly subjective measures of health status that were measured concurrently with financial decisions (Rosen and Wu, 2004; Edwards, 2008). Atella et al. (2012) and Bressan et al. (2014) find self-reported perceived health status to be related to stock market participation, while more objective measures of health status are not related to stock market participation. However, subjective measures of health most likely suffer from systematic measurement error making it difficult to interpret the estimation results. For example, a well-known justification bias indicates that individuals may report a worse subjective level of health to justify their current economic status (McGarry, 2004). This problem is particularly severe in research settings in which asset allocation is also self-reported.

Most notably, a recent paper by Cronqvist et al. (2016) has established the effect of two prenatal conditions - prenatal testosterone exposure and birth weight - on portfolio choice. They document that newborns with higher birth weight are more likely to participate in the stock market later in life. Lower birth weight is also associated with portfolios with higher volatility and skewness, consistent with compensatory behavior. While the twin study allows for explicit control of genetic background, twin birth weights are not representative of the overall population. Cronqvist et al. (2016) make an artificial upward distributional adjustment in their twin birth weight data to test the possible bias in their data. Our contribution in this paper is to validate this test with real population-based birth weight data.

Poterba et al. (2017) confirm a large and substantively meaningful correlation between a composite index of self-reported health and wealth accumulation in the U.S. context. Working the other way, Schwandt (2018) has reported that wealth shocks predict wealth changes and strongly affect health outcomes also using U.S. data. A unique contribution of our study to the existing empirical literature is that we use information on risk aversion and consider the role of risk aversion in adulthood as a potential mediator.

The paper proceeds as follows. Section 2 describes our empirical approach and data. Section 3 reports the baseline estimation results and robustness checks. Section 4 concludes and discusses future work.

\section{Data}

\subsection{Study design and sample}

We merge observations from the Northern Finland Birth Cohort (1966) (henceforth NFBC66) (University of Oulu, 1966) with stockholding data from the Finnish Central Securities Depository (FCSD). An impartial third party (Euroclear Finland) matched the data using personal social security numbers, preserving the subjects' data privacy.

The NFBC66 attempted to log all births with expected due dates in 1966 for the northern Finland provinces of Oulu and Lapland (Rantakallio, 1988). A total of 12,058 live births were recorded, constituting over $95 \%$ of all births in the two provinces over the year. The NFBC66 research group has conducted several follow-up studies over the years, using both clinical examinations and questionnaires (see http://www.oulu.fi/nfbc/node/44315 for details on the NFBC66 origin and data collections). The observations on measured birth weight, gender, and mother's education originate from the 1966 data collection. Importantly for our research setting, prenatal care has been uniform in Finland since the 1950s as a consequence of the construction of the national hospital network (Malin and Hemminki, 1992).

University education (defined as bachelor's degree or higher from a research university or university of applied sciences) was self-reported on the 31-year-old follow-up questionnaire in 1997. Moreover, we have access to risk aversion measures from the 46-year-old follow up study completed in 2012. The individuals gave permission to use the data while taking part in the follow-up studies. For the 31-year-old follow-up, of the 11,541 individuals with known address, data were obtained from 8767 and 8639 granted permission to use the data. ${ }^{2}$ For the 46 -year-old follow-up, of the 10,321 individuals with known address, 6774 responded to the survey and granted permission to use the data. ${ }^{3}$

The FCSD data contain the official holdings of registered securities in Finland. Stock market participation is based on information on equity security trades on the Helsinki Stock Exchange (NASDAQ OMX Helsinki). A total of 552 individuals who appear in the stockholdings data are defined as nonparticipants because they held only non-exchange-traded securities. A common example in our sample is holdings of Oulun Puhelin Oy, which was the mutually owned local telecommunications provider in the Oulu region. We do not place a lower limit on portfolio value or holding period in order to be labeled as a stock market participant (see Grinblatt and Keloharju (2000) and Conlin et al. (2015) for more detailed information on the FCSD data). The main sample we use is similar to that used in Conlin et al. (2015), but our estimation sample is larger because of the differing availability of the explanatory variables.

The main sample consists of 8639 individuals for whom we have observations of birth weight and stock market participation status and permission to use the data. The sample size is of sufficient statistical power to identify the relevant relationships. We use the data over the period of 1995-2010, when the persons included in NFBC66 were 29-44 years old. The sample is not necessarily representative of the population of Finland, to the extent that education differences of the parents or cohort members affect stock market participation or that the investing culture in northern Finland differs from that of the rest of Finland. Two points regarding the representativeness of the data are relevant. First, the average birth weight in our sample is in line with that of Vuori and Gissler (2012), who found an average birth weight of $3555 \mathrm{~g}$ for boys and $3433 \mathrm{~g}$ for girls for the entire country in the year 2011. In our data, the average weight for boys is $3554 \mathrm{~g}$, and the average weight for girls is $3430 \mathrm{~g}$. ${ }^{4}$ Second, the comprehensive register-based information on stockholding and the measures of risk aversion are an advantage.

\subsection{Measures}

Using the FCSD data, we describe financial decisions with two outcomes. The primary outcome variable is stock market participation. We define a stock market participant as an individual who held a position in at least one equity security traded on the Helsinki Stock Exchange (NASDAQ OMX Helsinki) during the years 1995-2010. Therefore, we use a conservative measure of non-participation because somebody who is only briefly in and then out still counts as a stock owner in our empirical specifications.

\footnotetext{
2 Please see https://www.oulu.fi/nfbc/node/30364 for more details on the 31-year-old follow-up study.

3 Please see https://www.oulu.fi/nfbc/node/26627 for more details on the 46-year-old follow-up study.

4 We note the difference in sample average birth weight between our sample (3490 g) and the sample of twins used in Cronqvist et al. (2016), which has average birth weight of $2414 \mathrm{~g}$.
} 
Early health status is potentially also related to the stock portfolio's composition because poor health may induce risk aversion leading to a preference for less-risky stocks. To measure the composition of investors' stock portfolios in terms of risk profile we use only those stock holdings that were publicly traded on the exchange in Helsinki (NASDAQ OMX). For each individual, we obtain information on the stocks held, the number of shares owned of each stock, and the value of each position at month-end over the period 2009-2010. The market-to-book values come from Thomson Reuters Datastream. We calculate the value-weighted market-to-book value of the portfolio at the end of each month for those month-end dates on which the individual held stocks (i.e., if the individual sold all stock holdings prior to month-end, we do not use a value of zero for the value-weighted market-to-book value of the portfolio). We then take the average of these month-end values over the 2009-2010 period as our observation of the portfolio's market-to-book ratio. This is the same measure of portfolio value-growth tilt used in Conlin and Miettunen (2017). The sample size for the stock portfolio composition analysis is naturally much smaller than that for the stock market participation analysis because these models are estimated conditional on stock market participation.

Early health status is measured by birth weight in grams. ${ }^{5}$ The estimate of risk aversion is the first principal component of responses to four survey questions on risk aversion in 2012 . $^{6}$ The four survey questions on risk aversion include two questions asking about the willingness to pay for an uncertain monetary outcome (as in Guiso and Paiella, 2008; Halko et al., 2012), a question nearly identical to that used in Barsky et al. (1997), and a question asking about general willingness to take risks (Dohmen et al., 2011). We acknowledge that the measure of risk aversion is observed after the sample period of our stock holdings data. If the individual's true level of risk aversion changed between the initial stock purchase and 2012, we will observe attenuation of the coefficient of the risk aversion term in the regressions (Bertrand and Mullainathan, 2001).

\subsection{Statistical methods}

We use ordinary least squares (OLS) models, implying that we estimate linear probability models. Although stock market participation is dichotomous, we estimate linear probability models because they are less sensitive to distributional assumptions (Wooldridge, 2001). ${ }^{7}$

In the baseline specification we control only for gender - a clearly predetermined variable. Note that there is no need to control for age because all participants in the NFBC66 were born in 1966. All cohort-specific effects are eliminated by definition. To account for family characteristics, we control for mother's education level. In additional specifications, we adjust for background characteristics (i.e., person's own education, income and wealth). These variables are "bad" controls in the sense that

\footnotetext{
5 Our working paper version reports results that use an indicator for those who had low birth weight using the standard definition for low birth weight $(<2500 \mathrm{~g})$ (WHO, 2010). The working paper version also reports results using the $\log$ of birth weight.

6 Figure A3 and Table A5 in the appendix provide further information on the survey questions and the principal component analysis.

7 We have checked the estimation results using probit and logit models. All our conclusions remain intact. For our main results in Table 2, there are only three cases of predicted probabilities being outside of the $[0,1]$ interval. The most extreme predicted probability of participation is -0.019 . Bertrand et al. (2004) suggest clustering standard errors at the level of variation in the policy variable of interest, e.g. clustering standard errors by states if regulation varies at the state level. We do not examine the effects of a policy variable that would lead to correlated residuals. Thus, we report heteroskedasticity-robust standard errors in all tables.
}

the covariates are at least partially determined by early health endowment (Black et al., 2007). We evaluate their relevance because concurrent educational attainment and related measures of socioeconomic status have been used extensively in the literature, which has examined the potential correlates of stock market participation (Grinblatt et al., 2011). Using the NFBC66, a person's education level is measured with an indicator for achieving a university degree by 1997. The income measure in 2012 originates from the comprehensive register maintained by the Finnish tax authorities. Net wealth is the self-reported value from the NFBC1966 follow-up survey conducted in $2012 .{ }^{8}$

In an effort to determine the direct effect of birth weight on stock market participation and stock portfolio composition, we use the Average Controlled Direct Effect method of Acharya et al. (2016). The method is used to estimate the direct effect of a treatment variable when control variables are likely to be affected by the treatment. In our specification, the treatment (birth weight) likely affects all our post-treatment controls (risk aversion, adult education, income, height, and wealth). We apply this method for the specification using stock market participation as the dependent variable and risk aversion as the only control. First, regress the outcome on the treatment and post-treatment mediator:

$Y_{i}=\alpha+\beta$ Birth_weight $_{i}+\gamma$ Risk_aversion $i+e_{i}$

Then, calculate the demediated outcome value. In this example, that would be:

$\tilde{Y}_{i}=Y_{i}-\widehat{\gamma}$ Risk_aversion $_{i}$

where $\widehat{\gamma}$ is the estimated coefficient on risk aversion from (1). Then regress the demediated value on the treatment:

$\tilde{Y}_{i}=c+\delta$ Birth_weight ${ }_{i}+\varepsilon_{i}$

The coefficient, $\delta$, gives the average controlled direct effect of birth weight on stock market participation. When including additional explanatory variables in the model, predetermined and post-treatment variables are included in (1); all post-treatment controls are used to demediate the outcome as in (2); all predetermined variables are included along with the treatment in (3). Please see Acharya et al. (2016) for more technical details on the method and Bietenbeck (2020) for a recent application of the method in economics.

The point estimates for birth weight effects are likely conservative for two reasons. First, the FCSD data do not include mutual fund share ownership information. Thus, the measure captures only "traditional" direct ownership of individual stocks. Risk averse persons may be more prone to hold well-diversified mutual funds than individual stocks leading to the underestimation of stock market participation. However, this is not a major limitation in our setting, because mutual fund ownership in Finland was still relatively uncommon during the early part of the observation window. The pension system that covers all citizens in Finland is run by the public sector. Second, if children with low birth weight have substantially higher mortality (Tommiska et al., 2001), the estimates constitute the lower bound for the true effect of low birth weight on stock market participation.

\section{Results}

\subsection{Descriptive evidence}

Table 1 reports descriptive statistics of the variables. The average measured birth weight is $3490 \mathrm{~g}$, and $16 \%$ of all persons participated in the stock market over the period of 1995-2010.

\footnotetext{
8 Wealth and total income may be reverse caused by portfolio choice. However, this is not a major concern is our setting, because median size of stock market ownership is small of the total wealth for individuals in the data.
} 
Table 1

Descriptive statistics.

\begin{tabular}{|c|c|c|c|c|c|c|}
\hline Variable & $\mathrm{N}$ & Mean & Median & Std. Dev. & Min. & Max. \\
\hline Birth weight (g) & 8639 & 3489.54 & 3500 & 527.62 & 1020 & 6080 \\
\hline Birth weight $<2500 \mathrm{~g}$ & 8639 & 0.036 & 0 & 0.187 & 0 & 1 \\
\hline Female & 8639 & 0.523 & 1 & 0.499 & 0 & 1 \\
\hline Height (cm, 1997) & 8346 & 171.34 & 171 & 9.186 & 107 & 202 \\
\hline University education (1997) & 8352 & 0.132 & 0 & 0.339 & 0 & 1 \\
\hline Income $€(1997)$ & 7556 & 29988 & 28592 & 21583 & 0 & 1000718 \\
\hline Net Wealth $€(2012)$ & 4705 & 207920 & 150000 & 215394 & 321 & 1200000 \\
\hline Stock mkt participation (1995-2010) & 8639 & 0.155 & 0 & 0.361 & 0 & 1 \\
\hline \multicolumn{7}{|l|}{ Mother's education (1966) } \\
\hline Basic & 8639 & 0.645 & 1 & 0.479 & 0 & 1 \\
\hline Vocational & 8639 & 0.184 & 0 & 0.387 & 0 & 1 \\
\hline Secondary & 8639 & 0.107 & 0 & 0.309 & 0 & 1 \\
\hline Graduate & 8639 & 0.049 & 0 & 0.216 & 0 & 1 \\
\hline \multicolumn{7}{|l|}{ Risk Aversion (2012) } \\
\hline Lottery & 5780 & 231 & 50 & 618 & 0 & 8000 \\
\hline Risky investment & 5694 & 1967 & 1000 & 2348 & 0 & 10000 \\
\hline Risky job & 5357 & 1.727 & 2 & 1.031 & 0 & 3 \\
\hline General risk & 5896 & 4.915 & 5 & 2.332 & 0 & 10 \\
\hline
\end{tabular}

Birth weight is normally distributed (Online Supplementary Appendix Figure A1). 9 Table A1 reports the pairwise correlation coefficients for the variables. Notably, birth weight is not strongly correlated with mother's education level most likely due to universal and affordable access to health care and a safety net provided by the comprehensive social security system. Although mean birth weight by mother's education increases monotonically, the relationship is not strong and only statistically significant difference in birth weight is for mothers who have basic education only vs. graduated (Table A2). In other institutional contexts such as U.S. birth weight has been shown to be quite strongly positively correlated with mother's education (Gage et al., 2013). Thus, the Finnish setting may be exceptional in this regard. The individual's own education level is significantly positively correlated with stock market participation (Table A1), which is consistent with the stylized facts of the literature (Grinblatt et al., 2011).

\subsection{Baseline estimates}

Table 2 reports the estimation results using stock market participation as the outcome variable. ${ }^{10}$ We find that birth weight is statistically significantly associated with higher stock market participation (Columns 1-3 of Panel A). The point estimate shows that a one standard deviation increase in birth weight is associated with a 1.9 percentage-point higher probability of stock market participation (Table 2, Panel A, Column 1).

Columns 2-4 of Table 2 add controls to the specification. We control for risk aversion (Column 2) and gender (Column 3). The estimate of risk aversion is the first principal component of responses to four survey questions on risk aversion from the NFBC66 46-year-old follow-up study conducted in 2012 (Figure A3 and Table A5). Any attenuation present due to the use of a measure from 2012 is not noticeable, as the coefficient on risk aversion is statistically significant at the one percent level across all model specifications. More risk averse persons have a much lower probability of being stock market participants, which is consistent with the literature (Hong et al., 2004). The point

\footnotetext{
9 Figure A2 shows the distribution of the share of wealth that is invested in stocks. There is a clear concentration at zero.

10 Figure A4 shows the stock market participation rate across birth weight deciles. We have also conducted analyses similar to Table 2 but using indicator variables for birth weight deciles instead of using continuous birth weight. Only deciles $5,7,8,9,10$ show statistically significant effects in the OLS regressions, and only deciles 8 and 10 have significant average controlled direct effects. Results available upon request.
}

estimate for birth weight is lower after controlling for risk aversion (Column 2). We interpret this result to suggest that at least part of the association between birth weight and stock market participation occurs through the association of lower birth weight with higher risk aversion. ${ }^{11}$ The addition of mother's education or a person's own education level in adulthood (Column 5-7) eliminates the association between birth weight and stock market participation in the OLS models.

\subsection{Additional specifications}

Acharya et al. (2016) apply a sequential procedure that consistently estimates the treatment effect while holding the values of potential mediators fixed. Adopting the approach, we estimate the average controlled direct effect of birth weight on stock market participation in Panel B of Table 2. These results generally provide support for the finding that birth weight is linked to stock market participation (also in Column 5) and the association is not completely channeled through the association between lower birth weight and risk aversion.

Nokia was the most popular single stock during the observation period. The Nokia effect is a potential contributor to the estimated links. Thus, we ran the OLS models after determining the participation status after removing all holdings of Nokia from the sample. There is no change in the results (not reported) because there are relatively few people who never held any stocks other than Nokia.

To examine the potential heterogeneity in the relationship, we estimated the models by gender. The link between birth weight and stock market participation seems to be limited to men (Tables A3-A4). However, this may be an issue of the sample - significantly fewer women participate in the stock market.

Because lower birth weight is associated with a lower likelihood of stock market participation, and the association seems to be at least partially channeled through risk aversion (Panel B of Table 2), we also seek to identify any association between birth weight and the stock portfolio's composition. In Table 3, we regress the average value-weighted market-to-book ratio of the individual's portfolio on birth weight, risk aversion, and the controls. We find no evidence that birth weight is related to the portfolio's tilt towards value or growth stocks. Risk aversion has a negative and statistically significant coefficient, indicating that higher risk aversion is associated with a tilt towards value stocks.

\footnotetext{
11 Our working paper version reports results that directly link lower birth weight to risk aversion.
} 
Table 2

The relationship between birth weight and stock market participation.

Panel A. Linear probability models

\begin{tabular}{|c|c|c|c|c|c|c|c|}
\hline & (1) & $(2)$ & (3) & (4) & $(5)$ & $(6)$ & (7) \\
\hline Birth weight & $\begin{array}{l}0.019^{* * *} \\
(0.004)\end{array}$ & $\begin{array}{l}0.013^{* *} \\
(0.005)\end{array}$ & $\begin{array}{l}0.013^{* * *} \\
(0.004)\end{array}$ & $\begin{array}{l}0.008 \\
(0.005)\end{array}$ & $\begin{array}{l}0.006 \\
(0.005)\end{array}$ & $\begin{array}{l}0.005 \\
(0.005)\end{array}$ & $\begin{array}{l}0.005 \\
(0.005)\end{array}$ \\
\hline RA factor & & $\begin{array}{l}-0.105^{\text {*** }} \\
(0.006)\end{array}$ & & $\begin{array}{l}-0.095^{* * *} \\
(0.006)\end{array}$ & $\begin{array}{l}-0.088^{* * *} \\
(0.006)\end{array}$ & $\begin{array}{l}-0.082^{* * *} \\
(0.006)\end{array}$ & $\begin{array}{l}-0.08^{* * *} \\
(0.006)\end{array}$ \\
\hline Female & & & $\begin{array}{l}-0.101^{* * *} \\
(0.008)\end{array}$ & $\begin{array}{l}-0.082^{* * *} \\
(0.011)\end{array}$ & $\begin{array}{l}-0.084^{* * *} \\
(0.011)\end{array}$ & $\begin{array}{l}-0.088^{* * *} \\
(0.011)\end{array}$ & $\begin{array}{l}-0.088^{* * *} \\
(0.011)\end{array}$ \\
\hline M. voc. ed. & & & & & $\begin{array}{l}0.029^{* *} \\
(0.013)\end{array}$ & $\begin{array}{l}0.017 \\
(0.013)\end{array}$ & $\begin{array}{l}0.016 \\
(0.014)\end{array}$ \\
\hline M. sec. ed. & & & & & $\begin{array}{l}0.128^{* * *} \\
(0.019)\end{array}$ & $\begin{array}{l}0.107^{* * *} \\
(0.019)\end{array}$ & $\begin{array}{l}0.11^{* * *} \\
(0.02)\end{array}$ \\
\hline M. graduate & & & & & $\begin{array}{l}0.213^{* * *} \\
(0.029)\end{array}$ & $\begin{array}{l}0.172^{* * *} \\
(0.029)\end{array}$ & $\begin{array}{l}0.17^{* * *} \\
(0.03)\end{array}$ \\
\hline University & & & & & & $\begin{array}{l}0.137^{* * *} \\
(0.017)\end{array}$ & $\begin{array}{l}0.126^{* * *} \\
(0.018)\end{array}$ \\
\hline Ln(Income) & & & & & & & $\begin{array}{l}0.035^{* * *} \\
(0.009)\end{array}$ \\
\hline Intercept & $\begin{array}{l}0.155 \\
(0.004)\end{array}$ & $\begin{array}{l}0.182 \\
(0.005)\end{array}$ & $\begin{array}{l}0.207 \\
(0.006)\end{array}$ & $\begin{array}{l}0.228 \\
(0.009)\end{array}$ & $\begin{array}{l}0.197 \\
(0.009)\end{array}$ & $\begin{array}{l}0.185 \\
(0.009)\end{array}$ & $\begin{array}{l}-0.165 \\
(0.09)\end{array}$ \\
\hline $\mathrm{R}^{2}$ & 0.003 & 0.076 & 0.022 & 0.086 & 0.109 & 0.126 & 0.13 \\
\hline $\mathrm{N}$ & 8639 & 5170 & 8639 & 5170 & 5170 & 5049 & 4653 \\
\hline \multicolumn{8}{|c|}{ Panel B. Average Controlled Direct Effect } \\
\hline & (1) & $(2)$ & (3) & (4) & (5) & (6) & (7) \\
\hline Birth weight & & $\begin{array}{l}0.019 * * * \\
(0.005)\end{array}$ & & $\begin{array}{l}0.011^{* *} \\
(0.005)\end{array}$ & $\begin{array}{l}0.009^{*} \\
(0.005)\end{array}$ & $\begin{array}{l}0.009 \\
(0.005)\end{array}$ & $\begin{array}{l}0.009 \\
(0.006)\end{array}$ \\
\hline
\end{tabular}

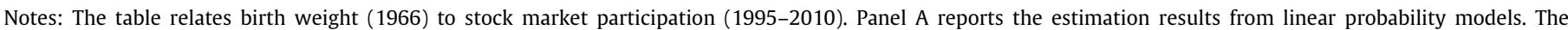

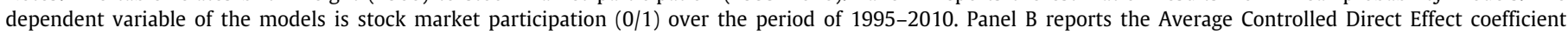

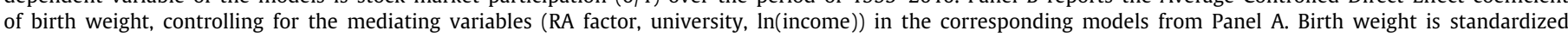

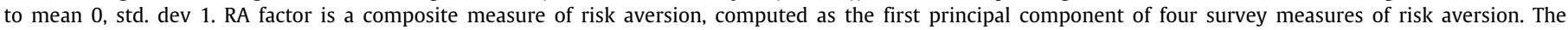

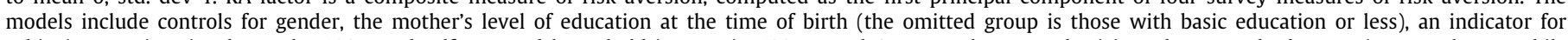

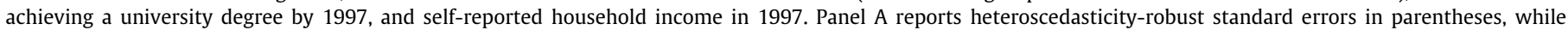
Panel B reports bootstrapped standard errors in parentheses. Both panels show significance at the * $10 \%{ }^{* *} 5 \%$ and ${ }^{* * *} 1 \%$ levels.

Table 3

The relationship between birth weight and stock portfolio composition.

\begin{tabular}{|c|c|c|c|c|c|c|c|}
\hline \multicolumn{8}{|l|}{ Panel A. OLS } \\
\hline & $(1)$ & $(2)$ & (3) & (4) & (5) & (6) & (7) \\
\hline Birth weight & $\begin{array}{l}-0.017 \\
(0.028)\end{array}$ & $\begin{array}{l}0.009 \\
(0.033)\end{array}$ & $\begin{array}{l}-0.016 \\
(0.028)\end{array}$ & $\begin{array}{l}0.012 \\
(0.034)\end{array}$ & $\begin{array}{l}0.011 \\
(0.034)\end{array}$ & $\begin{array}{l}0.005 \\
(0.032)\end{array}$ & $\begin{array}{l}0.007 \\
(0.034)\end{array}$ \\
\hline RA factor & & $\begin{array}{l}-0.071^{* * *} \\
(0.025)\end{array}$ & & $\begin{array}{l}-0.076^{* * *} \\
(0.027)\end{array}$ & $\begin{array}{l}-0.072^{* * *} \\
(0.027)\end{array}$ & $\begin{array}{l}-0.061^{* *} \\
(0.026)\end{array}$ & $\begin{array}{l}-0.061^{* *} \\
(0.028)\end{array}$ \\
\hline Female & & & $\begin{array}{l}0.02 \\
(0.059)\end{array}$ & $\begin{array}{l}0.04 \\
(0.069)\end{array}$ & $\begin{array}{l}0.025 \\
(0.071)\end{array}$ & $\begin{array}{l}0.001 \\
(0.07)\end{array}$ & $\begin{array}{l}-0.005 \\
(0.074)\end{array}$ \\
\hline M. voc. ed. & & & & & $\begin{array}{l}0.009 \\
(0.074)\end{array}$ & $\begin{array}{l}-0.013 \\
(0.073)\end{array}$ & $\begin{array}{l}0.013 \\
(0.076)\end{array}$ \\
\hline M. sec. ed. & & & & & $\begin{array}{l}0.092 \\
(0.085)\end{array}$ & $\begin{array}{l}0.042 \\
(0.084)\end{array}$ & $\begin{array}{l}0.031 \\
(0.086)\end{array}$ \\
\hline M. graduate & & & & & $\begin{array}{l}0.176 \\
(0.143)\end{array}$ & $\begin{array}{l}0.116 \\
(0.148)\end{array}$ & $\begin{array}{l}0.082 \\
(0.151)\end{array}$ \\
\hline University & & & & & & $\begin{array}{l}0.247^{* * *} \\
(0.076)\end{array}$ & $\begin{array}{l}0.199 * * * \\
(0.077)\end{array}$ \\
\hline Ln(Income) & & & & & & & $\begin{array}{l}0.098^{* *} \\
(0.044)\end{array}$ \\
\hline Intercept & $\begin{array}{l}1.849 \\
(0.027) \\
\end{array}$ & $\begin{array}{l}1.818 \\
(0.034) \\
\end{array}$ & $\begin{array}{c}1.842 \\
(0.03) \\
\end{array}$ & $\begin{array}{l}1.8 \\
(0.043) \\
\end{array}$ & $\begin{array}{l}1.769 \\
(0.049) \\
\end{array}$ & $\begin{array}{l}1.723 \\
(0.05) \\
\end{array}$ & $\begin{array}{l}0.729 \\
(0.452) \\
\end{array}$ \\
\hline $\mathrm{R}^{2}$ & 0 & 0.011 & 0.001 & 0.011 & 0.017 & 0.038 & 0.039 \\
\hline $\mathrm{N}$ & 962 & 697 & 962 & 697 & 697 & 684 & 647 \\
\hline \multicolumn{8}{|c|}{ Panel B. Average Controlled Direct Effect } \\
\hline & $(1)$ & (2) & (3) & (4) & (5) & (6) & (7) \\
\hline Birth weight & & $\begin{array}{l}0.014 \\
(0.033)\end{array}$ & & $\begin{array}{l}0.013 \\
(0.034)\end{array}$ & $\begin{array}{l}0.012 \\
(0.033)\end{array}$ & $\begin{array}{l}0.006 \\
(0.034)\end{array}$ & $\begin{array}{l}0.004 \\
(0.037)\end{array}$ \\
\hline
\end{tabular}

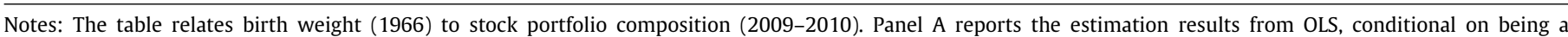

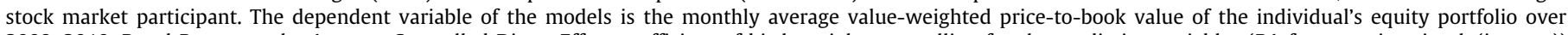

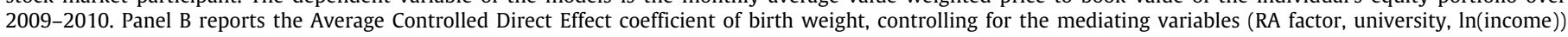

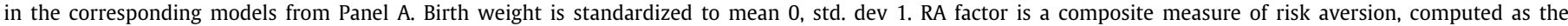

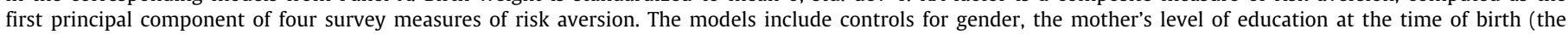

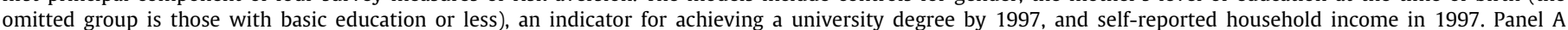

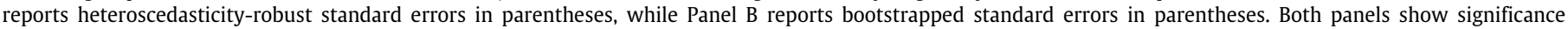
at the ${ }^{*} 10 \%{ }^{* *} 5 \%$ and ${ }^{* * *} 1 \%$ levels. 
Table 4

The relationship between birth weight and stock market participation controlling for adult height.

Panel A. Linear probability models

\begin{tabular}{|c|c|c|c|c|c|c|c|}
\hline & (1) & (2) & (3) & (4) & (5) & (6) & (7) \\
\hline Birth weight & $\begin{array}{l}0.006 \\
(0.004)\end{array}$ & $\begin{array}{l}0.004 \\
(0.005)\end{array}$ & $\begin{array}{l}0.008^{* *} \\
(0.004)\end{array}$ & $\begin{array}{l}0.006 \\
(0.005)\end{array}$ & $\begin{array}{l}0.006 \\
(0.005)\end{array}$ & $\begin{array}{l}0.006 \\
(0.005)\end{array}$ & $\begin{array}{l}0.006 \\
(0.006)\end{array}$ \\
\hline Height & $\begin{array}{l}0.051^{* * *} \\
(0.004)\end{array}$ & $\begin{array}{l}0.035^{* * *} \\
(0.006)\end{array}$ & $\begin{array}{l}0.026^{* * *} \\
(0.006)\end{array}$ & $\begin{array}{l}0.008 \\
(0.008)\end{array}$ & $\begin{array}{l}0.000 \\
(0.008)\end{array}$ & $\begin{array}{c}-0.004 \\
(0.008)\end{array}$ & $\begin{array}{c}-0.004 \\
(0.008)\end{array}$ \\
\hline RA factor & & $\begin{array}{l}-0.098^{* * *} \\
(0.006)\end{array}$ & & $\begin{array}{l}-0.095^{* * *} \\
(0.006)\end{array}$ & $\begin{array}{l}-0.088^{* * *} \\
(0.006)\end{array}$ & $\begin{array}{l}-0.082^{* * *} \\
(0.006)\end{array}$ & $\begin{array}{l}-0.08^{* * *} \\
(0.006)\end{array}$ \\
\hline Female & & & $\begin{array}{l}-0.065^{* * *} \\
(0.011)\end{array}$ & $\begin{array}{l}-0.07^{* * *} \\
(0.016)\end{array}$ & $\begin{array}{l}-0.083^{* * *} \\
(0.016)\end{array}$ & $\begin{array}{l}-0.093^{* * *} \\
(0.016)\end{array}$ & $\begin{array}{l}-0.094^{* * *} \\
(0.016)\end{array}$ \\
\hline M. voc. ed. & & & & & $\begin{array}{l}0.03^{* *} \\
(0.013)\end{array}$ & $\begin{array}{l}0.018 \\
(0.013)\end{array}$ & $\begin{array}{l}0.017 \\
(0.014)\end{array}$ \\
\hline M. sec. ed. & & & & & $\begin{array}{l}0.129^{* * *} \\
(0.019)\end{array}$ & $\begin{array}{l}0.107^{* * *} \\
(0.019)\end{array}$ & $\begin{array}{l}0.109^{* * *} \\
(0.02)\end{array}$ \\
\hline M. graduate & & & & & $\begin{array}{l}0.214^{* * *} \\
(0.029)\end{array}$ & $\begin{array}{l}0.173^{* * *} \\
(0.029)\end{array}$ & $\begin{array}{l}0.171^{* * *} \\
(0.03)\end{array}$ \\
\hline University & & & & & & $\begin{array}{l}0.136^{* * *} \\
(0.018)\end{array}$ & $\begin{array}{l}0.126^{* * *} \\
(0.018)\end{array}$ \\
\hline Ln(Income) & & & & & & & $\begin{array}{l}0.035^{* * *} \\
(0.009)\end{array}$ \\
\hline Intercept & $\begin{array}{l}0.157 \\
(0.004)\end{array}$ & $\begin{array}{l}0.183 \\
(0.005)\end{array}$ & $\begin{array}{l}0.191 \\
(0.008)\end{array}$ & $\begin{array}{l}0.221 \\
(0.01) \\
\end{array}$ & $\begin{array}{l}0.196 \\
(0.011)\end{array}$ & $\begin{array}{l}0.188 \\
(0.011)\end{array}$ & $\begin{array}{l}-0.163 \\
(0.091)\end{array}$ \\
\hline $\mathrm{R}^{2}$ & 0.021 & 0.084 & 0.024 & 0.087 & 0.11 & 0.125 & 0.13 \\
\hline $\mathrm{N}$ & 8346 & 5061 & 8346 & 5061 & 5061 & 5011 & 4623 \\
\hline \multicolumn{8}{|c|}{ Panel B. Average Controlled Direct Effect } \\
\hline & $(1)$ & $(2)$ & $(3)$ & $(4)$ & $(5)$ & (6) & $(7)$ \\
\hline Birth weight & $\begin{array}{l}0.019^{* * *} \\
(0.004)\end{array}$ & $\begin{array}{l}0.019 * * * \\
(0.006)\end{array}$ & $\begin{array}{l}0.013^{* * *} \\
(0.004)\end{array}$ & $\begin{array}{l}0.011^{*} \\
(0.006)\end{array}$ & $\begin{array}{l}0.009 \\
(0.006)\end{array}$ & $\begin{array}{l}0.009 \\
(0.005)\end{array}$ & $\begin{array}{l}0.009 \\
(0.006)\end{array}$ \\
\hline
\end{tabular}

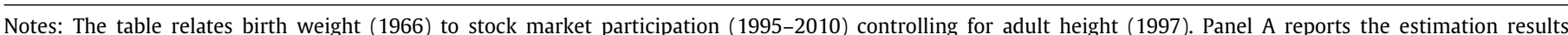

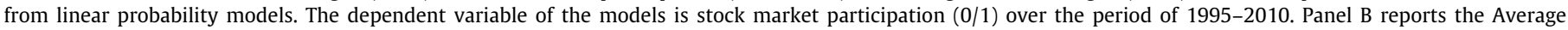

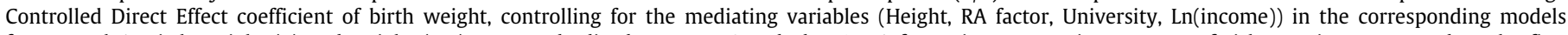

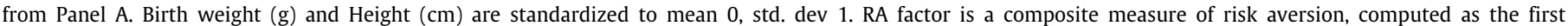

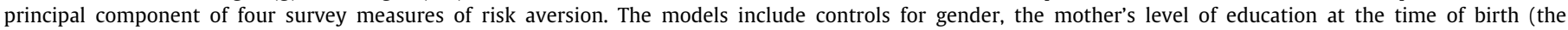

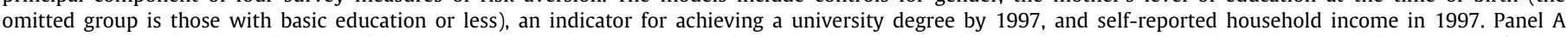

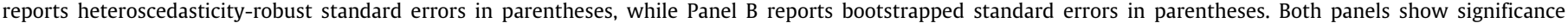
at the ${ }^{*} 10 \%{ }^{* *} 5 \%$ and ${ }^{* * *} 1 \%$ levels.

Individuals with a university degree hold portfolios with a tilt towards growth stocks.

We estimate models that include additional controls. First, we estimate models that control for measured adult height using NFBC66 from 1997. Height proxies for childhood health and neurocognitive development (Case and Paxson, 2008). We find that controlling for adult height eliminates the association between birth weight and stock market participation (Table 4). Taller persons are more likely to participate in the stock market. This relationship has not been highlighted much in the empirical literature. ${ }^{12}$ Second, we estimate models that control for wealth in 2012 to detect whether the link is mediated wealth (Table 5). Wealth is not a predetermined variable. Therefore, we do not include the variable in the baseline models. The results show that there is a significant positive association between wealth and stock market participation and the link between birth weight and stock market participation remains until we add controls for both risk aversion and gender.

The results presented so far show a significant relationship between birth weight and stock market participation (Tables 2, 4, and 5), but we find no relationship between birth weight and the stock portfolio's composition (Table 3). We perform an additional test that falls between these two outcomes: we test the relationship between birth weight and the share of wealth invested in stocks (Table A6). The results show that there is some evidence that birth weight is positively linked to the share of wealth invested in stocks. The effect of birth weight on the share of wealth invested remains after controlling for risk aversion, but

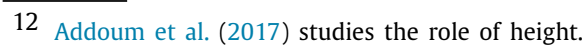

the effect drops out after other predetermined controls are added to the model specifications.

Like Cronqvist et al. (2016) we also perform a seemingly unrelated regression (SUR) analysis to further test the composition of direct and indirect effects for stock market participation. These results are presented in Table 6. The total effect is almost statistically meaningful ( $p=0.12$ ) and the risk preferences are clearly the strongest indirect effect both by the effect size (a quarter of the total effect) and statistical meaning $(\mathrm{p}=0.06)$ pointing to our basic hypothesis that risk aversion is the mediating channel of birth weight to stock market participation.

\section{Conclusions}

Poor health may hinder one's ability to rationally save or take appropriate risks. Using a longitudinal research design, we show that poor health status (measured using birth weight) is linked to lower stock market participation later in life. We also find that the link between birth weight and stock market participation is partially channeled by poor early health status being associated with higher risk aversion. Our results are related to the literature that has examined the long-term economic outcomes of low birth weight (Behrman and Rosenzweig, 2004; Black et al., 2007).

From a broader perspective, the findings are closely connected to the burgeoning literature that analyzes links between childhood factors (birth weight, height, obesity) and later life outcomes. Prenatal interventions that focus on the mother's nutritional and health standards may have positive effects in utero that improve health outcomes later in adulthood (Barker, 1997). Our results show that the effects of early health status are important determinants of financial decisions in adulthood as well, even in 
Table 5

The relationship between birth weight and stock market participation controlling for net wealth.

Panel A: OLS

\begin{tabular}{|c|c|c|c|c|c|c|c|}
\hline & (1) & $(2)$ & (3) & (4) & (5) & (6) & (7) \\
\hline Birth weight & $\begin{array}{l}0.02^{* * *} \\
(0.006)\end{array}$ & $\begin{array}{l}0.013^{* *} \\
(0.006)\end{array}$ & $\begin{array}{l}0.011^{* *} \\
(0.006)\end{array}$ & $\begin{array}{l}0.008 \\
(0.006)\end{array}$ & $\begin{array}{l}0.006 \\
(0.006)\end{array}$ & $\begin{array}{l}0.006 \\
(0.006)\end{array}$ & $\begin{array}{l}0.005 \\
(0.006)\end{array}$ \\
\hline Ln(wealth) & $\begin{array}{l}0.066^{* * *} \\
(0.004)\end{array}$ & $\begin{array}{l}0.05^{* * *} \\
(0.005)\end{array}$ & $\begin{array}{l}0.064^{* * *} \\
(0.004)\end{array}$ & $\begin{array}{l}0.05^{* * *} \\
(0.005)\end{array}$ & $\begin{array}{l}0.046^{* * *} \\
(0.005)\end{array}$ & $\begin{array}{l}0.04^{* * *} \\
(0.005)\end{array}$ & $\begin{array}{l}0.038^{* * *} \\
(0.005)\end{array}$ \\
\hline RA factor & & $\begin{array}{l}-0.095^{* * *} \\
(0.006)\end{array}$ & & $\begin{array}{l}-0.085^{* * *} \\
(0.006)\end{array}$ & $\begin{array}{l}-0.08^{* * *} \\
(0.006)\end{array}$ & $\begin{array}{l}-0.076^{* * *} \\
(0.006)\end{array}$ & $\begin{array}{l}-0.076^{* * *} \\
(0.007)\end{array}$ \\
\hline Female & & & $\begin{array}{l}-0.122^{* * *} \\
(0.011)\end{array}$ & $\begin{array}{l}-0.083^{* * *} \\
(0.012)\end{array}$ & $\begin{array}{l}-0.085^{* * *} \\
(0.012)\end{array}$ & $\begin{array}{l}-0.088^{* * *} \\
(0.012)\end{array}$ & $\begin{array}{l}-0.084^{* * *} \\
(0.013)\end{array}$ \\
\hline M. voc. ed. & & & & & $\begin{array}{l}0.023 \\
(0.015)\end{array}$ & $\begin{array}{l}0.012 \\
(0.015)\end{array}$ & $\begin{array}{l}0.011 \\
(0.016)\end{array}$ \\
\hline M. sec. ed. & & & & & $\begin{array}{l}0.115^{* * *} \\
(0.021)\end{array}$ & $\begin{array}{l}0.098^{* * *} \\
(0.021)\end{array}$ & $\begin{array}{l}0.1^{* * *} \\
(0.022)\end{array}$ \\
\hline M. graduate & & & & & $\begin{array}{l}0.19^{* * *} \\
(0.032)\end{array}$ & $\begin{array}{l}0.156^{* * *} \\
(0.032)\end{array}$ & $\begin{array}{l}0.157^{* * *} \\
(0.033)\end{array}$ \\
\hline University & & & & & & $\begin{array}{l}0.121^{* * *} \\
(0.019)\end{array}$ & $\begin{array}{l}0.118^{* * *} \\
(0.019)\end{array}$ \\
\hline Ln(Income) & & & & & & & $\begin{array}{l}0.013 \\
(0.011)\end{array}$ \\
\hline Intercept & $\begin{array}{l}-0.575 \\
(0.05)\end{array}$ & $\begin{array}{l}-0.393 \\
(0.053)\end{array}$ & $\begin{array}{l}-0.484 \\
(0.05)\end{array}$ & $\begin{array}{l}-0.35 \\
(0.053)\end{array}$ & $\begin{array}{l}-0.328 \\
(0.052)\end{array}$ & $\begin{array}{l}-0.268 \\
(0.053)\end{array}$ & $\begin{array}{l}-0.38 \\
(0.116)\end{array}$ \\
\hline $\mathrm{R}^{2}$ & 0.0465 & 0.1008 & 0.0694 & 0.1107 & 0.1278 & 0.1399 & 0.1382 \\
\hline $\mathrm{N}$ & 4705 & 4243 & 4705 & 4243 & 4243 & 4147 & 3885 \\
\hline \multicolumn{8}{|c|}{ Panel B. Average Controlled Direct Effect } \\
\hline & (1) & (2) & (3) & (4) & (5) & (6) & (7) \\
\hline Birth weight & $\begin{array}{l}0.023^{* * *} \\
(0.005)\end{array}$ & $\begin{array}{l}0.022^{* * *} \\
(0.006)\end{array}$ & $\begin{array}{l}0.014^{* * *} \\
(0.005)\end{array}$ & $\begin{array}{l}0.013^{* *} \\
(0.006)\end{array}$ & $\begin{array}{l}0.01^{*} \\
(0.006)\end{array}$ & $\begin{array}{l}0.011^{*} \\
(0.006)\end{array}$ & $\begin{array}{l}0.009 \\
(0.006)\end{array}$ \\
\hline
\end{tabular}

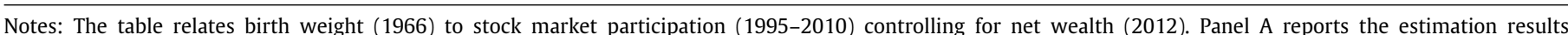

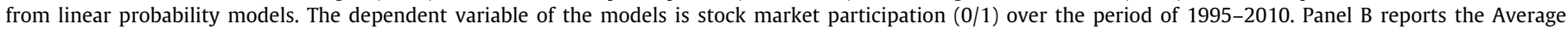

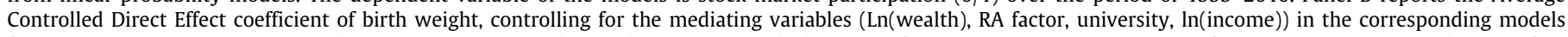

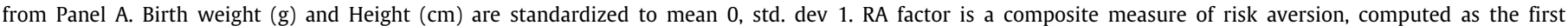

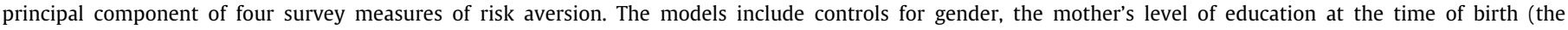

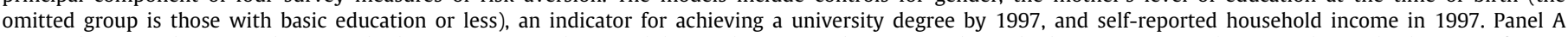

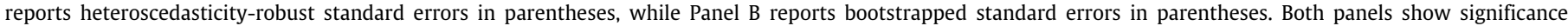
at the ${ }^{*} 10 \%{ }^{* *} 5 \%$ and ${ }^{* * *} 1 \%$ levels.

Table 6

Mediation analysis using seemingly unrelated regression.

\begin{tabular}{|c|c|c|c|c|c|}
\hline & & Coefficient & Std. Error & $p$-value & $\%$ of total \\
\hline \multicolumn{6}{|l|}{ Direct effect } \\
\hline & Birth weight & 0.00535 & $(0.00549)$ & 0.33 & 61.6 \\
\hline \multicolumn{6}{|l|}{ Indirect effect } \\
\hline & RA factor & 0.0023 & $(0.00123)$ & 0.06 & 26.5 \\
\hline & University & 0.00082 & $(0.00069)$ & 0.23 & 9.5 \\
\hline & Ln(Income) & 0.00021 & $(0.00034)$ & 0.54 & 2.4 \\
\hline & Combined indirect & 0.00334 & $(0.00162)$ & 0.04 & 38.4 \\
\hline \multicolumn{6}{|l|}{ Total effect } \\
\hline & Birth weight & 0.00869 & $(0.00565)$ & 0.12 & 100 \\
\hline
\end{tabular}

Notes: The table shows the results of mediation analysis performed using seemingly unrelated regression. The coefficients reflect the direct effects and indirect effects of birth weight (1966) on the probability of stock market participation (1995-2010). Birth weight $(\mathrm{g})$ is standardized to mean 0 , std. dev 1. RA factor is a composite measure of risk aversion, computed as the first principal component of four survey measures of risk aversion. University is an indicator variable for achieving a university degree by 1997, and Income is selfreported household income in 1997. All equations in the system contain controls for gender and the mother's level of education at the time of birth. Standard errors of the Indirect effects are calculated via bootstrap with 10,000 repetitions. p-values are reported for ease of interpretation. The last column is calculated as the coefficient value divided by the total effect.

a Nordic welfare state such as Finland. Thus, improving the level of neonatal care, a known correlate of birth weight, may support financial welfare since it is generally rational for everyone to invest at least a small amount in assets with a risk premium. Our results contrast with those of Atella et al. (2012), who find no relation between perceived concurrent health status and stock market participation in countries with a national health care system.
The fact that poor health leads to less-risky financial decisions later in life has important policy implications. All else equal, individuals who do not participate in the stock market likely accumulate less wealth than individuals who own stocks. A lower expected return on the financial portfolio implies that individuals with poor health status may be trapped in weaker income growth and lower wealth in the long run, which is also due, in part, to their financial choices. This adds to the economic hardships they face in life.

The strengths of the study are its relatively large sample, longitudinal research design, and excellent data on measured birth weight and comprehensive register-based information on stock market participation. However, a possible concern is that fetal conditions are correlated with other variables, possibly unobservable to the econometrician. Therefore, the role of birth weight in later-life outcomes is difficult to assess because birth weight is not completely exogenously determined but is dependent on factors that are difficult to measure, such as genetic makeup, early nutrition conditions and unmeasured parental background (Kramer, 1998). As a result, birthweight and health at birth might be proxying for other family characteristics, at least to some degree. There is evidence of the effects of parenting (Black et al., 2017) on financial risk-taking. We addressed this concern by examining the effect of controlling for mother's education. Because we analyze the issue within the context of a Nordic welfare state birth weight is not strongly correlated with the mother's education level - a notion supported by our data. Of course, there may be other family characteristics that mother's education does not fully capture. We are unable to identify the decisive causal mechanisms at play, but our evidence shows that the link between birth weight and stock market participation is at least 
partially channeled by poor early health status being associated with higher risk aversion in adulthood. It would be valuable if future research identified the remaining mechanisms.

\section{Declaration of competing interest}

The authors declare that they have no known competing financial interests or personal relationships that could have appeared to influence the work reported in this paper.

\section{Acknowledgments}

We thank all cohort members and researchers who participated in the $31 \mathrm{yrs}$ study and $46 \mathrm{yrs}$ study. We also wish to acknowledge the work of the NFBC project center. NFBC1966 received financial support from University of Oulu, Finland Grant no. 65354, Oulu University Hospital, Finland Grant no. 2/97, 8/97, Ministry of Health and Social Affairs Grant no. 23/251/97, 160/97, 190/97, National Institute for Health and Welfare, Helsinki, Finland Grant no. 54121, Regional Institute of Occupational Health, Oulu, Finland Grant no. 50621, 54231. NFBC1966 received financial support from University of Oulu, Finland Grant no. 24000692, Oulu University Hospital, Finland Grant no. 24301140, ERDF European Regional Development Fund Grant no. 539/2010 A31592. Böckerman thanks the Strategic Research Council funding for the project Work, Inequality and Public Policy (293120). Conlin thanks the OP Group Research Foundation for generous funding.

\section{Appendix A. Supplementary data}

Supplementary material related to this article can be found online at https://doi.org/10.1016/j.jbef.2021.100568.

\section{References}

Acharya, A., Blackwell, M., Sen, M., 2016. Explaining causal findings without bias: Detecting and assessing direct effects. Am. Political Sci. Rev. 110, 512-529.

Addoum, J.M., Korniotis, G., Kumar, A., 2017. Stature, obesity, and portfolio choice. Manage. Sci. 63, 3393-3413.

Almond, D., Currie, J., 2011. Killing me softly: The fetal origins hypothesis. J. Econ. Perspect. 25, 153-172.

Arrow, K.J., 1965. Aspects of the Theory of Risk-Bearing (Yrjö Jahnsson Lectures). Yrjö Jahnsson Foundation, Helsinki.

Atella, V., Brunetti, M., Maestas, N., 2012. Household portfolio choices, health status and health care systems: A cross-country analysis based on SHARE. J. Bank. Financ. 3, 1320-1335.

Barker, D.J., 1990. The fetal and infant origins of adult disease. BMJ: Br. Med. J. 301 (6761), 1111

Barker, D.J., 1997. Maternal nutrition, fetal nutrition, and disease in later life. Nutrition 13, 807-813.

Barsky, R.B., Juster, F.T., Kimball, M.S., Shapiro, M.D., 1997. Preference parameters and behavioral heterogeneity: An experimental approach in the health and retirement study. Q. J. Econ. 112, 537-579.

Behrman, J.R., Rosenzweig, M.R., 2004. Returns to birthweight. Rev. Econ. Stat. 86, 586-601.

Bertrand, M., Duflo, E., Mullainathan, S., 2004. How much should we trust differences-in-differences estimates? Q. J. Econ. 119, 249-275.

Bertrand, M., Mullainathan, S., 2001. Do people mean what they say? Implications for subjective survey data. Am. Econ. Rev. 91, 67-72.

Bietenbeck, J., 2020. The long-term impacts of low-achieving childhood peers: Evidence from project star. J. Eur. Econom. Assoc. 18, 392-426.

Black, S.E., Devereux, P.J., Lundborg, P., Majlesi, K., 2017. On the origins of risk-taking in financial markets. J. Finance 72, 2229-2278.
Black, S.E., Devereux, P.J., Salvanes, K., 2007. From the cradle to the labor market? The effect of birth weight on adult outcomes. Q. J. Econ. 122, 409-439.

Bressan, S., Pace, N., Pelizzon, L., 2014. Health status and portfolio choice: Is their relationship economically relevant? Int. Rev. Financ. Anal. 32, 109-122.

Case, A., Paxson, C., 2008. Stature and status: Height, ability, and labor market outcomes. J. Polit. Econ. 116, 499-532.

Conlin, A., Kyröläinen, P., Kaakinen, M., Järvelin, M.-R., Perttunen, J., Svento, R., 2015. Personality traits and stock market participation. J. Empir. Financ. 33, 34-50.

Conlin, A., Miettunen, J., 2017. Personality traits and portfolio tilts towards value and size. Manuscript. Available at SSRN: https://ssrn.com/abstract=3018383.

Corman, H., Dave, D.M., Reichman, N.E., 2017. Evolution of the Infant Health Production Function. Working Paper No. 24131, National Bureau of Economic Research.

Cronqvist, H., Previtero, A., Siegel, S., White, R.E., 2016. The fetal origins hypothesis in finance: Prenatal environment, the gender gap, and investor behavior. Rev. Financ. Stud. 29, 739-786.

Decker, S., Schmitz, H., 2016. Health shocks and risk aversion. J. Health Econ. 50, $156-170$

Dohmen, T., Falk, A., Huffman, D., Sunde, U., Schupp, J., Wagner, G.G., 2011. Individual risk attitudes: Measurement, determinants, and behavioral consequences. J. Eur. Econom. Assoc. 9, 522-550.

Edwards, R.D., 2008. Health risk and portfolio choice. J. Bus. Econom. Statist. 26, $472-485$.

Gage, T.B., Fang, F., O’Neill, E., DiRienzo, G., 2013. Maternal education, birth weight, and infant mortality in the United States. Demography 50, 615-635.

Grinblatt, M., Keloharju, M., 2000. The investment behavior and performance of various investor types: a study of Finland's unique data set. J. Financ. Econ. 55, 43-67.

Grinblatt, M., Keloharju, M., Linnainmaa, J., 2011. IQ and stock market participation. J. Finance 66, 2121-2164.

Guiso, L., Paiella, M., 2008. Risk aversion, wealth, and background risk. J. Eur. Econom. Assoc. 6, 1109-1150.

Halko, M.-L., Kaustia, M., Alanko, E., 2012. The gender effect in risky asset holdings. J. Econ. Behav. Organ. 83, 66-81.

Heckman, J.J., Stixrud, J., Urzua, S., 2006. The effects of cognitive and noncognitive abilities on labor market outcomes and social behavior. J. Labor Econ. 24, 411-482.

Hong, H., Kubik, J.D., Stein, J.C., 2004. Social interaction and stock-market participation. J. Finance 59, 137-163.

Kramer, M.S., 1998. Socioeconomic determinants of intrauterine growth retardation. Eur. J. Clin. Nutr. 52, S29-S32.

Malin, M., Hemminki, E., 1992. Midwives as providers of prenatal care in Finland - past and present. Women Health 18, 17-34.

McGarry, K., 2004. Health and retirement do changes in health affect retirement expectations? J. Hum. Resour. 39, 624-648.

Merton, R.C., 1969. Lifetime portfolio selection under uncertainty: the continuous-time case. Rev. Econ. Stat. 51, 247-257.

Northern Finland Birth Cohort, 1966. Website. http://www.oulu.fi/nfbc/node/ 44315 Accessed 1.11.2017.

University of Oulu, 1966. Northern Finland Birth Cohort 1966. University of Oulu. http://urn.fi/urn:nbn:fi:att:bc1e5408-980e-4a62-b899-43bec3755243.

Poterba, J.M., Venti, S.F., Wise, D.A., 2017. The asset cost of poor health. J. Econ. Ageing 9, 172-184.

Rantakallio, P., 1988. The longitudinal study of the northern Finland birth cohort of 1966. Paediatr. Perinat. Epidemiol. 2, 59-88.

Rosen, H.S., Wu, S., 2004. Portfolio choice and health status. J. Financ. Econ. 72, 457-484.

Schwandt, H., 2018. Wealth shocks and health outcomes: Evidence from stock market fluctuations. Am. Econ. J.: Appl. Econ. 10, 349-377.

Tommiska, V., Heinonen, K., Ikonen, S., et al., 2001. A national short-term follow-up study of extremely low birth weight infants born in Finland in 1996-1997. Pediatrics 107, e2.

Vuori, E., Gissler, M., 2012. Perinatal Statistics: Parturients, Deliveries and Newborns 2011. National Institute for Health and Welfare, Official Statistics of Finland, Helsinki.

WHO, 2010. International Statistical Classification of Diseases and Related Health Problems 10th Revision. World Health Organization.

Wooldridge, J.M., 2001. Econometric Analysis of Cross Section and Panel Data. MIT Press, Cambridge, MA. 